\author{
AGNIESZKA SZPAK \\ Uniwersytet Mikołaja Kopernika w Toruniu \\ Wydział Nauk o Polityce i Bezpieczeństwie \\ ORCID: 000-0001-7601-1230 \\ aszpak@umk.pl
}

\title{
JOANNA MODRZYŃSKA
}

Uniwersytet Mikołaja Kopernika w Toruniu Wydział Nauk o Polityce i Bezpieczeństwie ORCID: 0000-0002-5409-6787

joanna.modrzynska@umk.pl

\section{MICHAt DAHL}

Uniwersytet Mikołaja Kopernika w Toruniu Wydział Nauk o Polityce i Bezpieczeństwie ORCID: 0000-0003-2803-2648

dahl.michal@gmail.com

\section{Rola miast w czasach kryzysu multilateralizmu}

\section{The role of cities in times of crisis of multilateralism}

Słowa kluczowe:

miasta; multilateralizm; wielopoziomowe zarządzanie; sieci miast; pandemia COVID-19
Keywords:

cities; multilateralism; multi-level governance; cities' networks, coviD-19 pandemic 
The role of cities in times of crisis of multilateralism

The article shows how cities are nowadays stepping into the role of nation states and how they efficiently cooperate with other cities on transnational level, not only bilaterally but also multilaterally. The authors point to the clear symptoms of the crisis of the multilateralism and against this background focus on the role of cities in saving and/or fixing the multilateral system and solving global problems. An example of such activity is that of cities' during the current covid-19 pandemic. Finally, in the conclusions an attempt is made to answer the research question: can cities be regarded as a helping hand or a fix for the multilateral system? The research methods used are those of literature analysis and formal-legal analysis. The analysis made it possible to conclude that the answer to the research question is positive - cities may help to fix or even save the multilateral system. 


\section{Wprowadzenie}

łównym celem artykułu jest zaprezentowanie sposobu, w jaki miasta wkraczają w rolę państw narodowych i efektywnie współpracują z innymi ośrodkami samorządowymi przede wszystkim na płaszczyźnie transnarodowej - nie tylko dwustronnie, ale także wielostronnie. Świat XXI wieku jest nękany przez szereg nowych lub też wciąż istniejących problemów globalnych, które powinny być jak najszybciej rozwiązane. Należą do nich zmiany klimatyczne i ochrona środowiska, migracja i choroby, ale też trwająca właśnie pandemia coviD-19. Wiele wskazuje, że wszystkie te problemy mogą być rozwiązane przede wszystkim w drodze współpracy wielostronnej. Żadne państwo nie jest w stanie poradzić sobie $\mathrm{w}$ pojedynkę z tak różnorodnymi zadaniami. Niestety, obecnie można obserwować szereg niesprzyjających okoliczności, wśród których ważne miejsce zajmują kryzys multilateralizmu i wzrost nacjonalizmów. Jak argumentują Richard Ponzio i Joris Laris, obecny „zwrot antymultilateralistyczny" nie jest bynajmniej trendem zanikającym, o czym może świadczyć dojście do władzy byłego już prezydenta Donalda Trumpa w USA ${ }^{1}$, Jaira Bolsonaro w Brazylii lub Rodriga Duterte na Filipinach². Wszyscy oni głoszą hasła charakterystyczne dla wykluczającego nacjonalizmu,

1 Można tu wskazać hasło Donalda Trumpa - „America first”, odrzucenie TransPacific Partnership i Transatlantic Trade and Investment Partnership, decyzję o wystąpieniu z WHO, UNEsco, Rady Praw Człowieka ONZ i ONZ-owskiej Relief and Works Agency oraz wypowiedzenie: paryskiego porozumienia klimatycznego, Global Compact for Safe, Orderly and Regular Migration, Global Compact on Refugees, Intermediate-Range Nuclear Forces Treaty, Optional Protocol of the Vienna Convention on Diplomatic Relations and Treaty on Open Skies zob. Inaugural address: Trump's full speech [online], 21 I 2017 [dostęp: 8 II 2021], dostępne w internecie: <http://edition.cnn.com/2017/01/20/politics/trump-inaugural-address/>; O. Hathaway, Reengaging on treaties and other international agreements (part I): President Donald Trump's rejection of international law, Just Security, 2 X 2020 [dostęp: 8 II 2021], dostępny w internecie: <https://www.justsecurity. org/72656/reengaging-on-treaties-and-other-international-agreements-part-ipresident-donald-trumps-rejection-of-international-law/>.

2 Na przykład wypowiedzenie Statutu Międzynarodowego Trybunału Karnego zob. ICC List of States-parties, International Criminal Court [online], [dostęp: 8 II 2021], dostępny w internecie: <https://asp.icc-cpi.int/en_menus/asp/states\%2oparties/pages/the $\% 20$ states $\% 20$ parties $\% 20$ to $\% 20$ the $\% 20$ rome $\% 2$ ostatute.aspx $>$. 
eliminujące możliwość rozwijania współpracy regionalnej lub globalnej. Należy tu wspomnieć również o brexicie i rosnącym wpływie partii i ruchów skrajnie prawicowych, kwestionujących fundamenty, na których od zakończenia II wojny światowej budowane były Wspólnoty Europejskie. Pandemia covid-19 przyczyniła się do coraz częstszych reakcji w postaci zamykania granic i koncentrowania się państw tylko na własnych problemach. Ta ogólnoświatowa erozja powojennego porządku międzynarodowego i osłabienie poczucia wspólnoty międzynarodowej może utrudnić skuteczne radzenie sobie z transnarodowymi lub globalnymi wyzwaniami i problemami ${ }^{3}$. Wybór Joe Bidena na nowego prezydenta USA, wciąż jeszcze uznawanych za światowe mocarstwo, daje nadzieję na zmianę sytuacji, zwłaszcza biorąc pod uwagę jego pierwsze posunięcia odwołujące wiele decyzji poprzednika, w tym m.in. wstrzymanie procesu wychodzenia ze Światowej Organizacji Zdrowia oraz powrót do paryskiego porozumienia klimatycznego ${ }^{4}$. Pomimo nadziei związanych $\mathrm{z}$ wyborem i pierwszymi działaniami prezydenta Joe Bidena wciąż powszechne jest przekonanie, że wielostronna współpraca państw przeżywa kryzys. Powyższe przykłady to tylko kilka wybranych przejawów kryzysu multilateralizmu. Można zauważyć, że żyjemy w zdecydowanie mniej optymistycznym świecie czy też momencie dziejów niż jeszcze dekadę lub dwie temu. Z drugiej strony wielu ekspertów podziela opinię, że nowy prezydent USA daje nadzieję na bardziej bezpieczny świat i powrót do konstruktywnej, wielostronnej współpracy między państwami.

W tym kontekście trudno nie zwrócić uwagi na rosnącą rolę miast. Należy zauważyć, że obecnie są one w stanie wpływać na międzynarodowe inicjatywy w bezprecedensowym stopniu, być może nawet większym

3 R. Ponzio, J. Laris, 75 years on: remaking the case for the United Nations, Just Security, 15 IX 2020 [dostęp: 8 II 2021], dostępny w internecie: 〈https://www.justsecurity. org/72435/75-years-on-remaking-the-case-for-the-united-nations/ $>$.

4 M. Wierciszewski, USA wracaja do porozumienia paryskiego, "Rozpoczyna się nowy wyściog technologiczny”, „Business Insider” [online], 21 I 2021 [dostęp: 8 II 2021], dostępny w internecie: <https://businessinsider.com.pl/finanse/decyzja-joego-bidena-powrot-usa-do-porozumienia-paryskiego-konsekwencje-z-punktu/ qmo39wj>; Pierwsze podpisy Bidena. Anulowat częśc decyzji poprzednika, TVN24 [online], 21 I 2021 [dostęp: 8 II 2021], dostępny w internecie: <https://tvn24.pl/swiat/ usa-joe-biden-anulowal-czesc-decyzji-donalda-trumpa-pierwsze-podpisy-nowegoprezydenta-4978295>. 
niż renesansowe miasta-państwa ${ }^{5}$. Globalne problemy natury politycznej, społecznej, ekonomicznej i ekologicznej stają się coraz pilniejsze do rozwiązania, jednak rządy państw narodowych coraz częściej wydają się niezdolne lub niechętne do wspierania innowacyjnych działań politycznych na szczeblu międzynarodowym. Tę lukę starają się wypełniać miasta, które zarówno w kraju, jak i na świecie stają się coraz bardziej asertywne i wpływowe. Sytuacja ta może doprowadzić do głębokich zmian w polityce i prawie międzynarodowym ${ }^{6}$. W miarę jak miasta rosną $\mathrm{w}$ siłę, państwa stają się słabsze lub decydują się stanąć z boku w obliczu ogólnoświatowych zagrożeń, takich jak ekonomiczna globalizacja lub zmiany klimatu. Chociaż państwa dysponują takimi instrumentami debaty, dialogu i współpracy, jak np.: Ramowa konwencja Narodów Zjednoczonych w sprawie zmian klimatu, Światowa Organizacja Handlu czy Międzynarodowy Fundusz Walutowy, często nie są one $\mathrm{w}$ stanie stawić czoła problemom w dynamicznie zmieniających się okolicznościach, ponieważ zwykle działają zbyt wolno z powodu bezwładności, tak charakterystycznej dla dużych struktur. Ponadto umowy zawierane w ramach instytucji międzynarodowych, w przypadku których konieczne bywa wypracowanie kompromisu możliwego do przyjęcia dla wszystkich stron, często odzwierciedlają najniższy wspólny mianownik zamiast tak pożądanych katalogów zasad i praktyk, z których każdy mógłby wybrać optymalne rozwiązania pasujące do jego sytuacji. Tymczasem można zauważyć, że miasta są wyraźnie lepiej przygotowane do zajmowania się zagadnieniami związanymi z wyżej wymienionymi obszarami - mają wystarczający potencjał intelektualny i kulturowy, a także są częściami różnych sieci podobnych ośrodków, co ułatwia wymianę doświadczeń, dobrych praktyk czy realną współpracę. Trudno nie zauważyć, że dziś wiele z nich posiada większość cech tradycyjnie kojarzonych z państwami, poza suwerennością i prawem do użycia siły. Miasta wciąż jednak stoją w obliczu szeregu istotnych wyzwań. Pomimo tego, że

5 Ch. Swiney, S. Foster, Cities are rising in influence and power on the global stage, City Lab, 15 IV 2019 [dostęp: 8 II 2021], dostępny w internecie: <https://www.citylab.com/perspective/2019/o4/city-leadership-international-policy-mayors-u2O-uclgc40/587089/>.

6 Ch. Swiney, The urbanization of international law and international relations. The rising soft power of cities in global governance, „Michigan Journal of International Law" 2020, t. 41, nr 2, s. 228. 
przez 15 lat podjęto wiele wysiłków w ramach Milenijnych Celów Rozwoju, aby zapewnić zrównoważony rozwój, Narody Zjednoczone kontynuują działania - aktualnie w ramach Agendy Zrównoważonego Rozwoju. Nadal 828 milionów mieszkańców miast żyje na obszarach slumsów. Chociaż tylko $3 \%$ powierzchni lądowej Ziemi zajmują miasta, to zużywają one $60-80 \%$ energii wytwarzanej globalnie i odpowiadają za ok. $75 \%$ światowej emisji dwutlenku węgla ${ }^{7}$.

Powyższe wprowadzenie miało za zadanie zaprezentować kontekst i warunki, w których działają współczesne miasta. W kolejnym rozdziale autorzy przedstawią zagadnienia definicyjne multilateralizmu i dokonają przeglądu najbardziej reprezentatywnej literatury, w punkcie 3 zaś skupią się na roli miast w ratowaniu oraz/lub naprawianiu systemu wielostronnej współpracy i rozwiązywaniu problemów globalnych, wśród których dużą rolę odgrywa trwająca obecnie pandemia. Wreszcie w ramach konkluzji zostanie podjęta próba odpowiedzi na następujące pytania badawcze: Czy miasta są w stanie i mogą pomóc w naprawie systemu wielostronnego? Czy w sytuacji, kiedy do władzy w państwach dochodzą populiści bądź siły przeciwne multilateralnej współpracy, miasta mogą zaoferować jakieś skuteczne remedium?

Zastosowane metody badawcze objęły analizę literatury i analizę formalnoprawną (w odniesieniu do przytoczonych aktów prawnych i dokumentów).

\section{Aspekty definicyjne i przegląd literatury}

Zgodnie z definicją Roberta Keohane'a multilateralizm to praktyka polegająca na koordynowaniu polityk krajowych więcej niż dwóch państw - czy to instytucjonalnie, czy w drodze uzgodnień ad hoc. W świecie po 1945 roku rośnie znaczenie multilateralizmu w polityce międzynarodowej, o czym świadczy coraz większa liczba wielostronnych organizacji międzyrządowych czy konferencji międzynarodowych praktycznie na każdy temat ${ }^{8}$. Jednak

7 Goal 11. Sustainable cities and communities, Un Sustainable Development Goals, [dostęp: 8 II 2021], dostępny w internecie: <https://www.un.org/sustainabledevelopment/ cities/>.

8 R. O. Keohane, Multilateralism. An agenda for research, „International Journal” 1990, t. 45 , nr 4, s. 731 . 
Keohane wyraźnie ogranicza swoją definicję multilateralizmu do państw, chociaż jak zauważa John Ruggie, definicja ta jest jedynie nominalna ${ }^{9}$.

Zdecydowanie bardziej trafne wydaje się podejście Johna Ruggiego. Postrzega on bowiem multilateralizm jako podstawową formę instytucjonalną współczesnego życia międzynarodowego, która jest stosowana od wieków. Ogólne formy multilateralizmu można znaleźć w rozwiązaniach instytucjonalnych mających na celu zdefiniowanie i stabilizację międzynarodowych praw własności państw, zarządzanie problemami koordynacji między państwami oraz rozwiązywanie problemów związanych ze współpracą międzynarodową. Nie można jednak mylić tej ogólnej, instytucjonalnej formy multilateralizmu $\mathrm{z}$ formalną organizacją wielostronną ${ }^{10}$. Rugggie definiuje multilateralizm jako „formę instytucjonalną, która koordynuje stosunki między trzema lub więcej państwami na podstawie «uogólnionych» zasad postępowania - to znaczy zasad, które określają właściwe postępowanie dla pewnej kategorii działań, bez względu na partykularne interesy stron lub wymogi strategiczne, które mogą istnieć w każdym konkretnym przypadku"11. Podstawą koncepcji multilateralizmu Ruggiego jest pojęcie "formy architektonicznej”, którą postrzega jako „głęboko organizującą zasadę życia międzynarodowego"12. XX-wieczny zwrot w kierunku instytucji doprowadził do powstania wielostronnego porządku politycznego, który „jest w stanie sprostać przynajmniej niektórym zbiorowym zadaniom w sposób skoordynowany ex ante"13.

James A. Caporaso podkreśla, że w definicji terminu „wielostronny” kluczowym elementem jest współpraca. Każda działalność wielostronna musi obejmować współpracę, chociaż nie każdy jej przypadek lub forma jest wielostronna. Biorąc pod uwagę postrzeganie stosunków międzynarodowych przez Hobbesa jako bellum omnium contra omnes, nie można stwierdzić, że zachowania państw są wielostronne, chociaż ich interakcje są w dużym

9 J.G. Ruggie, Multilateralism: the Anatomy of an Institution, "International Organization" 1992, t. 46, nr 3, s. 565.

10 Ibidem, s. 567.

11 Ibidem, s. 571.

12 J. A. Caporaso, International relations theory and multilateralism. The search for foundations, "International Organization” 1992, t. 46, nr 3, s. 601-602.

13 J. G. Ruggie, Multilateralism..., s. 584; zob. także L. M. Martin, Interests, power, and multilateralism, „International Organization” 1992, t. 46, nr 4, s. 765-792. 
stopniu współzależne. Jednak niektóre państwa można wyraźnie uznać za prowadzące wielostronne działania przeciwko innym, np. jako część sojuszu wojskowego ${ }^{14}$.

Wszystkie powyższe podejścia ograniczają zakres definicji multilateralizmu do państw. Jednak na potrzeby niniejszego artykułu zakres ten został poszerzony i objął aktorów subpaństwowych lub subnarodowych, czyli miasta. Oczywiście bardzo istotnym przejawem multilateralizmu są organizacje międzynarodowe, które stanowią forum dla współpracy państw, jednak niniejszy tekst skupiać się będzie przede wszystkim na działalności miast. Należy zauważyć, że zakres współpracy wzajemnej miast można nazwać transnarodowym. Ten szerszy zakres multilateralizmu jest związany ze znaczeniem pojęć „systemu międzynarodowego” lub „wspólnoty międzynarodowej". Przykładowo Simon Curtis argumentuje, że zjawisko "globalnego miasta" wyraźnie wskazuje na fakt, iż dzisiejszy system międzynarodowy wykazuje zauważalne tendencje transformacyjne. $\mathrm{Z}$ historycznego punktu widzenia, pozwalającego na zastosowanie koncepcji la longue durée, która nadaje priorytet długoterminowym strukturom historycznym, analiza tego systemu ujawnia wiele różnych form i struktur kolejnych systemów międzynarodowych. To z kolei daje podstawy do badania długich okresów i wyciągania wniosków opartych na historycznych wzorcach i trendach. W tym ujęciu współczesny system międzynarodowy jest tylko konfiguracją specyficzną historycznie, wynikającą z jednej z wielu możliwych kombinacji terytorium, formy państwa i organizującej system czy też wiodącej zasady suwerenności państwa. Inne połączenia z całą gamą form instytucjonalnych i logik organizacyjnych można znaleźć w zapisach historycznych. Przez długie okresy historii ludzkości system międzynarodowy obejmował szereg różnych organizmów: imperia, państwa narodowe, państwa-miasta, ligi miejskie, wolne miasta, a także ludy koczownicze o luźniejszym przywiązaniu do terytorium ${ }^{15}$.

Curtis dodaje, że miasta mogą korzystać ze swojej sprawczości (aǵency) w ramach systemów międzynarodowych, a tym samym być postrzegane jako podmioty podobne do innych, nawet jeśli ich sprawczość ma specyficzny charakter. Suwerenne państwa, ligi miejskie i miasta-państwa - wszystkie

14 J. A. Caporaso, International relations..., s. 603.

15 S. Curtis, Global cities and the transformation of the international system, ProQuest, Ann Arbor 2014, s. 7, 58-59. 
te formy mogą być częścią systemu przyszłości i trudno jest teraz przewidzieć, która $\mathrm{z}$ nich będzie dominować ${ }^{16}$. Rosnąca pozycja miast wywołała spekulacje co do kształtowania się tzw. neośredniowiecza, którego cechami wyróżniającymi są nieterytorialne, nakładające się strefy wpływów i autorytetów ${ }^{17}$.

Również bogata literatura na temat wielopoziomowego zarządzenia/ rządzenia (ang. multi-level governance) uzasadnia zjawisko rosnącej sprawczości miast. Wielopoziomowe zarządzanie to pojęcie używane do opisania sposobu dystrybucji władzy między państwami a licznymi organizacjami i podmiotami quasi-rządowymi i pozarządowymi. Istnieje kilka powodów występowania tego zjawiska. Niezależny wpływ podmiotów ponadnarodowych na tworzenie polityki pozbawił państwa ich tradycyjnego monopolu. W wielu dziedzinach państwa straciły kontrolę również z powodu rosnącej złożoności problemów, które wymagają kolektywnego podejmowania decyzji, a sieci polityk łączą dziś na wiele przeplatających się sposobów areny polityczne na wszystkich poziomach - subnarodowym, narodowym i ponadnarodowym. Wszystko to doprowadziło do sytuacji, w której podmioty działające na różnych szczeblach zarządzania w coraz większym stopniu dzielą kompetencje między sobą. To z kolei podkreśla znaczenie sposobu, w jaki władza polityczna i proces tworzenia polityki działają ponad tradycyjnymi podziałami między podmiotami państwowymi i niepaństwowymi, a także między areną międzynarodową i wewnętrzną ${ }^{18}$. Termin "wielopoziomowe zarządzanie" został użyty, aby w uproszczony sposób przedstawić pojęcie pluralistycznej, silnie rozproszonej działalności, którą jest dziś tworzenie polityki z wieloma jej uczestnikami (zarówno instytucjami, jak i jednostkami) działającymi na wszystkich poziomach, od lokalnego do ponadnarodowego. Niezależnie od różnic przestrzennych i separacji geograficznej kluczową częścią wielopoziomowego zarządzania są liczne powiązania łączące wszystkie poziomy. To, co implikuje wielopoziomowe zarządzanie, to wpływ i zaangażowanie (oba poziomy aktywności są tu równe) oraz wzajemna zależność tworzona przez splecione działania $\mathrm{w}$ ramach kształtowania

16 S. Curtis, Global cities and..., s. 87, 95.

17 Ibidem, s. 102.

18 M. M. Betsill, H. Bulkeley, Cities and the multilevel governance of global climate change, "Global Governance" 2006, t. 12, nr 2, s. 149. 
różnych polityk ${ }^{19}$. Philippe Schmitter i Sunhyuk Kim definiują wielopoziomowe zarządzanie jako 'sposób podejmowania wiążących decyzji, który angażuje wielu aktorów publicznych i prywatnych, współzależnych we wszystkich aspektach poza politycznym'. Podmioty te pochodzą z różnych poziomów agregacji terytorialnej, która jest stale omawiana, negocjowana i wdrażana; jednak w żadnym wypadku nie przypisuje to żadnej wyłącznej kompetencji politycznej któremukolwiek z tych poziomów ani nie potwierdza żadnego stałego, hierarchicznego autorytetu w polityce ${ }^{20}$.

Zamiast akumulować władzę, wielopoziomowe zarządzanie promuje jej rozproszenie $^{21}$. Z założenia tego wynika, że kompetencje i uprawnienia są rozproszone i redystrybuowane na różnych poziomach tworzenia polityki, tak pomiędzy stare, jak i nowe podmioty i instytucje, a raczej aktorów prywatnych i publicznych ${ }^{22}$. Wielopoziomowe zarządzanie wzmocniło pozycję podmiotów działających poniżej poziomu krajowego, oferując im szeroki dostęp do informacji i angażując je w podejmowanie decyzji - „nieformalne i nieuporządkowane zarządzanie dotyczy i nakłada na siebie uporządkowane i formalne zarządzanie" ${ }^{\prime 23}$. Dziś miasta mogą być doskonale zlokalizowane w sieci takich podmiotów. Mają do odegrania ważną rolę w rozwiązywaniu problemów, nawet tych globalnych, takich jak zmiany klimatu i zrównoważony rozwój.

Na podstawie dotychczasowych badań można wyróżnić dwie generacje wielopoziomowego sprawowania rządów ${ }^{24}$. Pierwsza z nich była ściśle związana z pojawieniem się polityki regionalnej i jednolitego rynku na poziomie polityki europejskiej ${ }^{25}$. W rezultacie wiele debat koncentrowało się

19 P. Stephenson, Twenty years of multi-level governance: 'Where Does it Come From? What is it? Where Is It Going?', „Journal of European Public Policy” 2013, t. 20, nr 6, s. 817.

20 P. Schmitter, S. Kim, The experience of European integration and the potential for Northeast Asian integration, East-West Center Working Papers, nr 10, August 2005, s. 5, [dostęp: 27 VII 2021], dostępny w internecie: <http://www.eastwestcenter.org/ sites/default/files/private/PSwpo10.pdf>.

21 P. Stephenson, Twenty years..., s. 821; L. Hooghe, G. Marks, Multi-level governance and European integration, Rowman \& Littlefield Publishers, Oxford 2001, s. 3.

22 P. Stephenson, Twenty years..., s. 828.

23 Ibidem, s. 824 .

24 Ibidem.

25 B. Kohler-Koch, Research on EU governance: insight from a stock-taking exercise, "Connex Newsletter" 2006, nr 3; Multi-level governance, red. I. Bache, M. Flinders Oxford University Press, Oxford 2004. 
na partnerstwie i koordynacji na różnych etapach procesu tworzenia polityki. Część tej dyskusji doprowadziła do utworzenia Komitetu Regionów UE. Komitet ten postrzega wielopoziomowe zarządzanie jako obejmujące instytucje ponadnarodowe podejmujące skoordynowane działania związane $\mathrm{z}$ przygotowaniem i realizacją polityk UE, w których ich partnerami są władze lokalne, regionalne i krajowe ${ }^{26}$. Stąd pierwsza generacja skoncentrowała się na państwach i regionalnych organizacjach międzynarodowych (międzyrządowych) - dominowały w niej komponenty rządowe. Druga generacja miała odmienny charakter ze względu na fakt, że proces tworzenia polityki opierał się nie tylko na organizacjach publicznych, ale także organizacjach prywatnych i podmiotach pozarządowych, skupiając się tym samym na podmiotach innych niż państwa i organizacje międzynarodowe/międzyrządowe. $\mathrm{W}$ tym kontekście $\mathrm{w}$ wielopoziomowym zarządzaniu nadal brakowało perspektywy miast, ponieważ są one podmiotami publicznymi, a nie prywatnymi, i jako samorządy działają na szczeblu niższym niż krajowy ${ }^{27}$. Według autorów niniejszego tekstu w odniesieniu do współczesnych miast i ich działalności można mówić o trzeciej generacji paradygmatu wielopoziomowego zarządzania.

Bezpośrednie kontakty między miastami i ich wzajemną pomoc ponad granicami państw można określić mianem dyplomacji miejskiej (ang. city diplomacy). Taką dwustronną i wielostronną dyplomację miejską można traktować jako narzędzie współpracy, pokoju i zrównoważonego rozwoju ${ }^{28}$. Literatura $\mathrm{w}$ tym zakresie zawiera wiele ciekawych pozycji, z których na szczególną uwagę zasługują: City diplomacy. Current trends and future prospects pod red. S. Amiri i E. Sevin (2020), R. van der Pluijm i J. Melissen, City diplomacy: The expanding role of cities in international politics (2007) oraz L. K. Grandi, City diplomacy (2020 $)^{29}$.

26 P. Stephenson, Twenty years..., s. 822.

27 Ibidem, s. 822 .

28 L. K. Grandi, City diplomacy, Palgrave Macmillan, Cham 2020.

29 City diplomacy. Current trends and future prospects, red. S. Amiri, E. Sevin, Palgrave Macmillan, Cham 2020; R. van der Pluijm, J. Melissen, City diplomacy: The expanding role of cities in international politics, Netherlands Institute of International Relations Clingendael, The Hague 2007, dostępny w internecie [dostęp: 24 VII 2021]: https://www.uclg.org/sites/default/files/20070400_cdsp_paper_pluijm.pdf; L. K. Grandi, City diplomacy, Palgrave Macmillan, Cham 2020. 
Także publikacje z zakresu prawa międzynarodowego i stosunków międzynarodowych dostrzegają rosnącą rolę miast. Wśród tych pierwszych należy wyróżnić artykuły Yishai Blanka oraz Geralda Fruga i Davida Barrona opublikowane w 2006 roku $^{30}$ (ten ostatni ukuł termin „międzynarodowe prawo samorządowe", aby podkreślić nowość i kompleksowość powstających międzynarodowych przepisów prawnych dotyczących miast). Ponadto istnieje kilka publikacji na temat miast w prawie międzynarodowym: artykuły i rozdziały w książkach, np. tekst zatytułowany Megacities Jeana-Bernarda Auby $(2011)^{31}$ lub esej przeglądowy Shining cities on the hill? autorstwa Helmuta Philippa Austa $(2015)^{32}$. Ten ostatni wskazuje na potrzebę analizy pozycji miast w prawie międzynarodowym. Choć ostatnie lata przyniosły istotne zmiany, wiele aspektów związanych z miastami, w tym kwestie prawne, jest wciąż niedostatecznie zbadanych.

W literaturze dotyczącej stosunków międzynarodowych znaleźć można więcej tekstów poświęconych temu zagadnieniu, ale brakuje wyczerpującej analizy problematyki rosnącej roli miast $\mathrm{w}$ stosunkach międzynarodowych, ich udziału w globalnych systemach rządzenia, w procesach decyzyjnych dotyczących prawa międzynarodowego i jego eǵzekwowania. Do najważniejszych tekstów z zakresu stosunków międzynarodowych i literatury politologicznej należą: P. J. Taylor et al., Cities in globalization. Practices, policies and theories (2007), S. Curtis (red.), The power of cities in international relations (2014), M. Amen et al. (red.), Cities and global governance. New sites for international relations (2011) ${ }^{33}$, D. E. Davis, N. L. de Duren (red.), Cities and sovereignty. Identity politics in urban spaces (2011) czy F. Alger, The UN system and cities in global governance (2014) ${ }^{34}$. Istnieją również książki należące raczej

30 Y. Blank, The city and the world, "Columbia Journal of Transnational Law” 2006, t. 44, nr 3, s. 868-931; G. Frug, D. Barron, International Local Government, „The Urban Lawyer" 2006, t. 38, nr 1, s. 1-62.

31 J.-B. Auby, Mega-cities, 'Glocalisation and the law of the future', [w:] The law of the future and the future of law, red. S. Muler et al., Torkel Opsahl Academic EPublisher, Oslo 2011, s. 203-211.

32 H.-P. Aust, Shining cities on the hill? The global city, climate change, and international law, „European Journal of International Law” 2015, t. 26, nr 1, s. 255-278.

33 Cities and global governance. New sites for international relations, red. M. Amen et al., Ashgate, Farnham 2011.

34 P. J. Taylor et al., Cities in globalization. Practices, policies and theories, Routledge, London 2007; The power of cities in international relations, red. S. Curtis, Routledge, 
do dziedziny socjologii, takie jak przełomowe teksty Saskii Sassen, The global city (1991) ${ }^{35}$, które dały początek określeniu "miasto globalne”, Arnaldo Baǵnasco i Patricka Le Galès'a, Cities in contemporary Europe (2009) ${ }^{36}$ czy The economy of cities Jane Jacobs (1970) ${ }^{37}$. Jedną z najważniejszych publikacji ostatnich lat jest książka Benjamina Barbera Gdyby burmistrzowie rzadzili światem. Dysfunkcyjne kraje, rozkwitające miasta ${ }^{38}$, w której autor przedstawia i promuje koncepcję, zgodnie z którą miasta, jako lepsze w radzeniu sobie z globalnymi wyzwaniami - od kwestii klimatycznych po bezpieczeństwo narodowe - mogą i powinny częściowo zastąpić państwa. Wymienione prace przedstawiają różne płaszczyzny funkcjonowania miast: ich wciąż rosnące znaczenie dla gospodarki i kultury, działalność w dobie globalizacji gospodarczej oraz ewoluujące relacje społeczne, a także ich nieoficjalne relacje nawiązywane i utrzymywane przez prywatnych aktorów (np. firmy). Wśród najbardziej aktualnych publikacji można wskazać teksty: Barbary Oomen i Moritza Baumgärtela, Frontier cities. The rise of local authorities as an opportunity for International Human Rights Law (2018) ${ }^{39}$, Chrystie Swiney, The urbanization of international law and international relations. The rising soft power of cities in global governance (2020) ${ }^{40}$ oraz Louisa Eslavy i George'a Hilla, Cities, post-coloniality and international law $(2020)^{41}$, których autorzy podkreślają potrzebę uznania nowych aktorów - miast - i ich roli w wielopoziomowym zarządzaniu.

New York 2014; Cities and sovereignty. Identity politics in urban spaces, red. D. E. Davis, N. L. de Duren, Indiana University Press, Bloomington, Indianapolis 2011; Ch. F. Alger, The UN system and cities in global governance, Springer, Cham 2014.

35 S. Sassen, The global city, Princeton University Press, Oxford 1991.

36 Cities in contemporary Europe, red. A. Bagnasco, P. Le Gales, Cambridge University Press, Cambridge, 2009.

37 J. Jacobs, The Economy of Cities, Vintage Books, New York 1970.

38 B. Barber, Gdyby burmistrzowie rzadzili światem. Dysfunkcyjne kraje, rozkwitające miasta, przeł. H. Jankowska, K. Makaruk, Muza, Warszawa, 2014.

39 B. Oomen, M. Baumgärtel, Frontier cities. The rise of local authorities as an opportunity for International Human Rights Law, „European Journal of International Law” 2018, t. 29, nr 2, s. 607-630.

40 Ch. Swiney, The urbanization of..., s. 227-278.

41 L. Eslava, G. Hill, Cities, post-coloniality and international law [online], 29 VI 2020 [dostęp: 8 II 2021], dostępny w internecie: <https://papers.ssrn.com/sol3/papers.cfm? abstract_id $=3617676>$. 
Rosnąca rola miast i intensyfikacja procesów globalizacji wymagają nowego podejścia do miast jako coraz ważniejszych aktorów globalnego wielopoziomowego zarządzania. Mimo obecności na łamach wymienionych publikacji miasta są jednak nadal niedostatecznie reprezentowane w literaturze z zakresu stosunków międzynarodowych, w tym w analizach polityki zagranicznej oraz prawa międzynarodowego. $\mathrm{W}$ tym drugim przypadku są one niemalże nieobecne, zwłaszcza w podręcznikach prawa międzynarodowego.

W polskiej literaturze, tytułem przykładu, można wskazać publikacje Anny Karwińskiej i Agnieszki Brzosko-Sermak, Dobrze funkcjonujące miasto. Koncepcje, cechy, perspektywy rozwoju z 2014 r. czy Marty Lackowskiej, Miejska polityka „zagraniczna”. Koncepcja przeskalowania $w$ doświadczeniach polskich miast z $2014 \mathrm{r}^{42}$.

\section{Wielostronne działania miast}

Zmiany klimatyczne, szerzenie się chorób zakaźnych, rosnące w siłę ekstremizmy, upadek demokracji, światowy kryzys migracyjny, niedobór tanich mieszkań oraz rosnące podziały między narodami i grupami społecznymi, a także w ich obrębie - te i inne globalne wyzwania, przed którymi stoi dziś ludzkość, stają się palące, a rządy poszczególnych państw przyjmują postawę coraz bardziej niechętną bądź okazują się niezdolne do przyjęcia i wdrożenia międzynarodowej postępowej polityki mającej na celu rozwiązanie tych problemów. Jednocześnie to miasta podejmują działania i zwalczają kryzysy - często z poparciem lub za zgodą władz krajowych - chociaż zdarzają się sytuacje, że i bez takiej aprobaty. W ten sposób miasta stają się coraz bardziej wpływowe i asertywne zarówno na poziomie krajowym, jak i międzynarodowym, powodując zmianę paradygmatu w tradycyjnym podejściu do globalnej polityki i prawa ${ }^{43}$.

Wielostronne działania miast są najczęściej prowadzone za pośrednictwem ich biur/departamentów stosunków międzynarodowych/współpracy

42 A. Karwińska, A. Brzosko-Sermak, Dobrze funkcjonujące miasto. Koncepcje, cechy, perspektywy rozwoju, Wydawnictwo UEK, Kraków, 2014; M. Lackowska, Miejska polityka „zagraniczna”. Koncepcja przeskalowania w doświadczeniach polskich miast, Wydawnictwo Uniwersytetu Warszawskiego, Warszawa, 2014.

43 Ch. Swiney, The urbanization of ..., s. 228. 
międzynarodowej oraz sieci miast (takich jak na przykład Eurocities lub United Cities and Local Governments). Takie działania są czasami nazywane "wielostronną dyplomacją miejską" (ang. multilateral city diplomacy). W wielu przypadkach w miejsce dotychczasowych działań ad hoc miasta zaczęły przyjmować własne długofalowe polityki w zakresie stosunków międzynarodowych. Dobrym przykładem takiego przedsięwzięcia są działania podjęte przez Barcelonę. W 2020 r. Rada miasta Barcelony przyjęła Barcelona International Relations Master Plan, który jest „zobowiązaniem do transformacyjnej polityki międzynarodowej, która promuje i broni modelu miasta opartego na postępie społecznym, prawach człowieka, technologicznym humanizmie, sprawiedliwości klimatycznej i feminizmie"44. Barcelona dokłada wszelkich starań, aby umocnić swoją pozycję jako miasta globalnego i otwartego. To tutaj powstały znane sieci miast - United Cities and Local Governments (UCLG) oraz Metropolis ${ }^{45}$. Barcelona stworzyła również własne instytucje i politykę, aby promować i wzmacniać swą pozycję na całym świecie ${ }^{46}$. Wśród priorytetów obecnego barcelońskiego Master Plan znalazły się m.in. takie cele jak: wzmocnienie sojuszy strategicznych zarówno na szczeblu lokalnym, jak i międzynarodowym oraz wspieranie adaptacji systemu wielostronnego do bardziej inkluzywnej formy, umożliwiającej miastom aktywny udział na arenie międzynarodowej oraz ochronę interesów miasta i jego mieszkańców. Wyraźnie widać tu odniesienie do multilateralizmu. Biorąc pod uwagę ogólnoświatową tendencję do jednostronnego wycofywania się państw z różnych zobowiązań i organizacji międzynarodowych, Barcelona postrzega tę ostatnią reformę jako priorytet, skuteczniejszy niż zwykła obrona status quo. Dziś to miasta są najbardziej dotknięte kryzysami, ale są też miejscami, w których pojawia się najwięcej możliwości; w związku z tym muszą mieć możliwość uczestniczenia w rozwiązywaniu problemów globalnych na szczeblu międzynarodowym.

44 Barcelona, global city. International relations master plan 2020-2023, Ajuntament de Barcelona, July 2020, s. 3, dostępny w internecie [dostęp: 8 II 2021]: <https://ajuntament.barcelona.cat/relacionsinternacionalsicooperacio/sites/default/files/bcn_ir_ master_plan.pdf $>$.

45 Zob. aneks International network of cities do Barcelona, global city. International relations master..., s. 24-25.

46 Barcelona, global city. International relations master plan..., s. 5. 
Nie można zmienić miast bez uwzględnienia świata, którego są one częścią; głosy mieszkańców miast i ich przedstawicieli muszą być słyszalne na arenie międzynarodowej ${ }^{47}$.

Interpretując powyższe cele, można przede wszystkim wyraźnie dostrzec, że miasta ewidentnie stały się bardziej proaktywne w obszarze praw człowieka, przejmując coraz częściej rolę przywódców politycznych w zakresie wdrażania tych praw ${ }^{48}$. Michele Grigolo twierdzi, że "miasta praw człowieka" (ang. human rights cities) mogły powstać w ramach szerszego procesu transformacji państwa. W tym procesie dyskurs o prawach człowieka zyskał również lokalne znaczenie, a obecnie jest postrzegany jako część obowiązków samorządów. Nie jest zaskakujące, że rządy centralne chętnie delegują te zadania na niższy szczebel; zaangażowanie się w prawa człowieka daje jednak samorządom szansę na wzmocnienie ich pozycji w państwie i domaganie się zwiększenia czy też uznania krajowej i międzynarodowej widoczności, a nawet autonomii wobec państwa ${ }^{49}$. Miasta podejmują również wiele inicjatyw i działań mających na celu rozwiązanie takich globalnych problemów jak zmiany klimatyczne czy migracja. W tej ostatniej kwestii (dotyczącej m.in. uchodźców i migrantów ekonomicznych) bardzo niedawno - po spaleniu obozu dla uchodźców Moria w Grecji 8 września 2020 r. - europejskie miasta zaoferowały pomoc, przyjmując poszkodowanych. Na przykład osiem niemieckich miast, w tym Kolonia, Düsseldorf, Hanower i Münster, które uczestniczą we współpracy w ramach Eurocities, wysłało do rządu list z prośbą o pozwolenie na przyjęcie osób z Morii. „Jesteśmy gotowi” - ogłosił burmistrz Münster, Markus Lewe. Włodarze Amsterdamu, Barcelony i Walencji wspólnie zwrócili się do czołowych instytucji UE, również oferując przyjęcie uchodźców i wzywając do silniejszej solidarności europejskiej. Już w kwietniu 2020 r., w odpowiedzi na doniesienia o przerażającej sytuacji w obozach dla uchodźców na wyspach greckich, wiele miast europejskich stwierdziło, że są gotowe zapewnić lepsze warunki mieszkającym tam najbardziej zagrożonym migrantom. W liście do szefów Komisji Europejskiej, Rady Europejskiej

47 Barcelona, global city. International relations master plan..., s. 18.

48 M. Grigolo, Local governments and human rights. Some critical reflections, „Columbia Human Rights Law Review" 2017, t. 49, nr 1, s. 69.

49 Ibidem, s. 73. 
i Parlamentu Europejskiego burmistrzowie zaproponowali m.in. przyjęcie dzieci pozostających bez opieki ${ }^{50}$.

Istnieje wiele przypadków, w których miasta wdrażają konwencje praw człowieka, które nie zostały ratyfikowane przez ich państwa. $\mathrm{Na}$ przykład globalna sieć miast Child Friendly Cities Initiative ma na celu bezpośrednie wdrażanie konwencji praw dziecka na terytoriach miast członkowskich. Celem Międzynarodowej Koalicji Miast przeciwko Rasizmowi i Dyskryminacji, powstałej pod auspicjami UNEsco, jest bezpośrednie wprowadzenie $\mathrm{w}$ życie norm antydyskryminacyjnych i antyrasistowskich zapisanych w traktatach międzynarodowych lub zawartych w prawie zwyczajowym $^{51}$. Chociaż Stany Zjednoczone nie ratyfikowały Konwencji oNZ w sprawie likwidacji wszelkich form dyskryminacji kobiet, Los Angeles i San Francisco zatwierdziły ją i realizują jej postanowienia ${ }^{52}$. Salt Lake City zobowiązało się do wypełnienia zobowiązań wynikających z protokołu z Kioto (nieratyfikowanego przez USA), tj. redukcji emisji gazów cieplarnianych $w$ celu przeciwdziałania globalnemu ociepleniu ${ }^{53}$.

Przykładem miasta realizującego umowę międzynarodową bez ratyfikacji traktatu przez państwo był apel burmistrza Seattle Grega Nickelsa z 2005 r. skierowany do innych miast, w którym wezwał je do wdrożenia protokołu z Kioto poprzez lokalne przepisy przewidujące zmniejszenie poziomu emisji gazów cieplarnianych. Po pozytywnej odpowiedzi powstała sieć ponad tysiąca miast pod nazwą U.S. Mayors Climate Protection Agreement ${ }^{54}$.

50 Moria fire - cities ready to take in refugees, Eurocities, 10 IX 2020 [dostęp: 8 II 2021], dostępny w internecie: <https://eurocities.eu/latest/moria-fire-citiesready-to-take-in-refugees/ $>$.

51 G. Frug, D. Barron, International local government, „The Urban Lawyer” 2006, t. 38, nr 1, s. 22; J. Nijman, The future of the city and the international law of the future, [w:] The law of the future and the future of law, red. S. Muller i in., Torkel Opsahl Academic EPublisher, Olso 2011, s. 222-223.

52 K. Knop, International law and the disaggregated democratic state. Two case studies on women's human rights and the United States, Rapoport Center Human Rights, (Working Paper Series 2012, 6), dostępny w internecie [dostęp: 23 VII 2021]: <https://aw.utexas.edu/humanrights/projects/ international-law-and-the-disaggregated-democratic-state/ $>$.

53 J. Nijman, The future..., s. 224.

54 Ibidem, s. 222. 
W tym samym duchu, w odpowiedzi na niesławne uzasadnienie wycofania się USA z paryskiego porozumienia klimatycznego przez prezydenta Trumpa - w którym stwierdził on, że został "wybrany do reprezentowania obywateli Pittsburgha, a nie Paryża" - burmistrz Bill Peduto obiecał, że Pittsburgh będzie przestrzegać porozumienia paryskiego, gdyż leży to w najlepszym interesie gospodarki miasta i jego mieszkańców ${ }^{55}$. W ramach reakcji na decyzję Trumpa powstała inicjatywa America's Pledge, która miała na celu raportowanie działań amerykańskich stanów, miast, przedsiębiorstw i organizacji, podejmowanych w celu obniżenia przez nie emisji gazów cieplarnianych zgodnie z celami porozumienia paryskiego ${ }^{56}$. Interesującego przykładu dostarcza brytyjskie miasto York. Podczas gdy Wielka Brytania z reguły sprzeciwiała się ustawie o prawach człowieka, York celowo wykorzystywał międzynarodowe prawa człowieka jako ramy dla swojej lokalnej polityki. Miasto zdecydowało się również złagodzić rosnącą dotkliwość krajowej polityki migracyjnej poprzez przyjmowanie uchodźców ${ }^{57}$.

Stosunkowo nowym przykładem wielostronnej współpracy miast jest Pakt Wolnych Miast, podpisany w Budapeszcie 16 grudnia 2019 r. przez cztery środkowoeuropejskie stolice: Bratysławę, Budapeszt, Pragę i Warszawę. Ich włodarze podjęli starania o zawarcie porozumienia motywowani faktem, że we wszystkich państwach narodowych władze centralne i samorządowe dość często nie zgadzają się co do priorytetów realizowanej polityki. Sytuacja ta nie dziwi, zważywszy, że burmistrzowie stolic państw Grupy Wyszehradzkiej są członkami partii opozycyjnych wobec obecnych rządów centralnych. Cele zawarte w Pakcie można podzielić na trzy kategorie: (1) ochrona i promocja wspólnych wartości; (2) dzielenie się najlepszymi praktykami i wspólna praca nad projektami rozwoju obszarów miejskich; oraz (3) opowiadanie się w instytucjach UE za bezpośrednim finansowaniem miast, nawet do tego stopnia, żeby w razie potrzeby można

55 A. Roberts, Beyond the globalism/nationalism divide. The rise of cities and corporations seeking international obligations, Opinio Juris, 3 VI 2017 [dostęp: 8 II 2021], s. 12, dostępny w internecie: <http://opiniojuris.org/2017/o6/o3/beyond-globalismnationalism-divide-rise-cities-corporations-seeking-international-obligations/ $>$.

56 About America's Pledge, America's Pledge, [dostęp: 8 II 2021], dostępny w internecie: 〈https://www.americaspledgeonclimate.com/about/>.

57 J.Lin, Governing climate change. Global cities and transnational lawmaking, Cambridge University Press, Cambridge 2018, s. 48. 
było pominąć władze centralne, a tym samym zwiększyć fundusze czterech uczestniczących miast. Przywódcy miast zaznaczyli, że przed zawarciem paktu pytali Komisję Europejską i Dyrekcję Generalną odpowiedzialną za rozwój regionalny UE o zasadność takiego rozwiązania, a przedstawiciele tych instytucji to potwierdzili ${ }^{58}$.

Ponadto miasta (Barcelona to tylko jeden z przykładów) zauważają, że system wielostronnej współpracy przechodzi obecnie kryzys i wymaga reform. Bardzo donośny głos miast w tym samym duchu został wyrażony we wspólnej deklaracji politycznej w ramach wirtualnego szczytu burmistrzów w Mannheim (2020). W deklaracji włodarze miast stwierdzili, że "miasta w systemie oNZ są ważnymi partnerami dla utrzymania wielostronnego, opartego na zasadach porządku światowego i dlateǵo muszą być trwale zintegrowane z procesami i strukturami dalszego rozwoju multilateralizmu”. Ponadto dodali, iż „osiągnięcie celów wspólnoty narodów, zwłaszcza w obszarze zrównoważonego rozwoju, może odnieść sukces tylko dzięki redefinicji roli miast w systemie Narodów Zjednoczonych i dlatego istnieje potrzeba reformy instytucjonalnej Organizacji Narodów Zjednoczonych, która ostatecznie doprowadzi do sformalizowanego udziału miast $\mathrm{w}$ procesach decyzyjnych Organizacji Narodów Zjednoczonych" ${ }^{n 9}$. Wspólną deklarację przekazano kanclerz Niemiec Angeli Merkel i sekretarzowi generalnemu ONZ António Guterresowi z żądaniem uwzględniania postulatów miasta Mannheim i jego miast partnerskich w debatach o przyszłości społeczności międzynarodowej podczas dorocznej sesji Zgromadzenia Ogólnego ONZ we wrześniu 2020 r. W tym samym miesiącu Światowy Parlament Burmistrzów (Global Parliament of Mayors GPM) w liście otwartym do ONZ zwrócił się o uznanie znaczenia miast w dzisiejszym globalnym systemie politycznym - wielostronnym i opartym na wypracowanych zasadach. GPM zaproponował również otwarcie

58 W. Szymański, Pakt wolnych stolic przeciwko populistom, Deutsche Welle [online], 9 XI 2019 [dostęp: 24 VII 2021], dostępny w internecie: https:/www.dw.com/pl/pakt-wolnych-stolic-przeciwko-populistom/a-51180702; A. Dimitrova, Mayors of Bratislava, Budapest, Prague and Warsaw sign Free Cities Pact, The Mayor.eu, 17 XII 2019 [dostęp: 24 VII 2021], dostępny w internecie: 〈https://www.themayor.eu/en/a/view/ mayors-of-bratislava-budapest-prague-and-warsaw-sign-free-cities-pact-3945 $>$.

59 Joint Political Declaration within the scope of the virtual mayor's summit in Mannheim, 9 IX 2020 [dostęp: 8 II 2021], dostępny w internecie: <https://www.mannheim. de/sites/default/files/2020-09/EN_Declaration_formated.pdf $\rangle$. 
ogólnoświatowej dyskusji na temat kształtu i zakresu reformy instytucjonalnej, która sformalizowałaby udział miast w podejmowaniu decyzji na szczeblu międzynarodowym. Burmistrzowie zaapelowali do Sekretarza Generalnego ONZ António Guterresa o zainicjowanie i kierowanie taką globalną debatą, w której miasta i ich przywódcy będą w pełni uczestniczyć. Miałaby ona dotyczyć reformy oNZ i przekształcenia obecnego porządku światowego, tak aby miasta i ich mieszkańcy byli również reprezentowani w systemach globalnych. Globalne zarządzanie powinno zostać przekształcone w system, w którym miasta i ich sieci będą miały równą z państwami pozycję $\mathrm{w}$ podejmowaniu decyzji i prowadzeniu polityki na tym poziomie. Obecny format globalnego zarządzania, który obejmuje głównie interakcje między narodami i wyklucza innych przywódców politycznych lub instytucjonalnych, nie jest już $\mathrm{w}$ stanie poradzić sobie $\mathrm{z}$ obecną formą i zakresem globalnych wyzwań, od przyspieszenia zmiany klimatu po kryzys migracyjny, od polityki tożsamości po kwestie bezpieczeństwa, od niewydolnej opieki zdrowotnej po wciąż powszechne ubóstwo. GPM zwrócił się o otwarcie okresu przejściowego i rozpoczęcie wspomnianej debaty na temat najbardziej efektywnych sposobów zapewnienia reprezentacji miast w strukturze ONZ. W konkluzji listu otwartego zaproponowano, że 75 lat po założeniu ONZ należałoby zainicjować transformację organizacji w „Organizację Zjednoczonych Narodów i Miast Świata”, ponieważ „globalna społeczność miejska (urbanity) musi być reprezentowana w globalnym systemie rządów"60.

Wszystko to jest niezwykle ważne, szczególnie w kontekście obecnej pandemii coviD-19. Gdy cała społeczność międzynarodowa staje w obliczu zagrożenia związanego z pandemią, warto pamiętać, że są też aktorzy, inni niż państwa, którzy mają do odegrania ważną rolę w walce z tym zagrożeniem, a tymi aktorami są właśnie miasta. Władza państw może być niewystarczająca do zajmowania się np. globalnym ociepleniem, globalizacją gospodarczą lub trwającą pandemią; z kolei miasta często są wolne od ograniczeń wiążących państwa, dzięki czemu mogą działać efektywnie, wykorzystując w walce swój intelektualny, kulturowy i ekonomiczny potencjał.

60 Open letter to UN Secretary-General H. E. Mr. António Guterres, Global Parliament of Mayors, 10 IX 2020 [dostęp: 8 II 2021], dostępny w internecie: 〈https://globalparliamentofmayors.org/gpm-open-letter-to-un-secretary-general/>. 
Odnotowano wiele przypadków wielostronnej współpracy miast, nie tylko na najbardziej oczywistym poziomie, jak wymiana pomysłów między miastami połączonymi bliskością geograficzną, ale także rzeczywiste przypadki współpracy w ramach sieci międzynarodowych lub regionalnych, jak również przykłady miast wykorzystujących udział państwa przyjmującego w określonej organizacji globalnej. Dla przykładu celem programu International Urban Cooperation - elementu unijnej strategii promowania zrównoważonego rozwoju obszarów miejskich poprzez współpracę z sektorem publicznym i prywatnym - jest wspieranie powiązań między miastami, a tym samym podejmowanie działań ułatwiających wymianę rozwiązań wspólnych problemów ${ }^{61}$.

Podczas wideokonferencji, która odbyła się 9 kwietnia 2020 r., miasta, takie jak: Barcelona, Bolonia, Granada, Manchester, Mannheim, Rzym, Stuttgart i Nicea, a także Liuzhou (prowincja Guangxi, południowe Chiny), dyskutowały o najlepszych sposobach ograniczania i łagodzenia skutków pandemii CoviD-19 oraz o przygotowywaniu gruntu pod przyszłą, postpandemiczną odbudowę gospodarki i społeczeństwa. Istotnym elementem tego spotkania była współpraca z miastami chińskimi, które nie tylko dzieliły się bogatszym doświadczeniem i wypracowanymi rozwiązaniami $\mathrm{w}$ walce $\mathrm{z}$ koronawirusem, ale także oferowały namacalne formy wsparcia (np.: przed konferencją miasto Mannheim przyjęło od swojego partnera - Qingdao - duży transport wysokiej jakości maseczek). Planowane są dalsze konferencje europejsko-azjatyckie w ramach International Urban Cooperation UE w celu ułatwienia wymiany danych i rozwiązań - przede wszystkim, aby pomóc sobie nawzajem $\mathrm{w}$ obliczu trwającego kryzysu, a następnie skupić się na współpracy w dziedzinie zrównoważonego rozwoju obszarów miejskich ${ }^{62}$.

Anna Rudakowska i Craig Simon przekonują, że w obliczu pandemii coviD-19 miastom udało się zachować wizerunek skutecznych aktorów, skupionych na praktycznej stronie walki z zagrożeniem. Autorzy twierdzą,

61 International Urban Cooperation. European Union, [dostęp: 8 II 2021], dostępny w internecie: 〈https://iuc.eu/home〉.

62 EU-China cities discuss the management of COVID-19, European Commission, 14 IV 2020 [dostęp: 8 II 2021], dostępny w internecie: <https://ec.europa.eu/regional_policy/en/ newsroom/news/2020/04/14-04-2020-eu-china-cities-discuss-the-management-ofcovid-19>. 
że były one i wciąż są w stanie działać szybciej i skuteczniej niż państwa z dwóch powodów. Po pierwsze, ich liczne sieci i dwustronne relacje stały się skutecznymi kanałami wzajemnej wymiany porad, doświadczeń, dobrych praktyk i kluczowych danych między miastami. Po drugie, skuteczność takiej komunikacji w dużej mierze wynikała z nieformalności i prostoty tych powiązań. Anna Rudakowska i Craig Simon zastanawiają się również, czy dyplomacja miejska może pomóc uratować system wielostronnej współpracy i czy zaufanie między miastami może przyczynić się do budowania bardziej „przewidywalnego i stabilnego porządku światowego" ${ }^{\text {" } 33}$. Warto zauważyć, że od początku pandemii Covid-19 $\mathrm{w}$ wielu przypadkach działania miast uzupełniały działania państw narodowych, w tym podejmowanie zobowiązań międzynarodowych bez uprzedniej zgody państw przyjmujących, co było bezpośrednim skutkiem niespotykanej dotąd na taką skalę presji czasu.

\section{Wnioski}

Postawione na początku artykułu pytania badawcze brzmiały: Czy miasta mogą pomóc w naprawie wielostronnej współpracy? Czy w sytuacji, gdy do władzy dochodzą populiści i/lub przeciwnicy multilateralnej współpracy, miasta mogą zaoferować jakieś remedium? Z powyższej analizy wynika, że miasta mają ogromny potencjał, który może być rozwijany i wykorzystywany w przyszłości. Rosnąca obecnie rola miast powoduje, że coraz częściej podejmują one działania, które są kluczowe dla utrzymania wielostronnej współpracy. Tam, gdzie państwa zawodzą, często to właśnie miasta odnoszą sukcesy; tam, gdzie państwa nie są w stanie współpracować lub współpraca jest zbyt powolna, wkraczają miasta i wyciągają pomocną dłoń. Przykłady miast współpracujących podczas pandemii coviD-19, deklaracja z Mannheim, amerykańskie miasta wdrażające konwencje nieratyfikowane przez państwo, Pakt Wolnych Miast czy Barcelona International Relations Master Plan potwierdzają, że miasta stanowią coraz ważniejszy

63 A. Rudakowska, C. Simon, International city cooperation in the fight against COVID-19. Behind the scenes security providers, "Global Policy” [online], 3 IX 2020 [dostęp: 8 II 2021], dostępny w internecie: <https://www.globalpolicyjournal.com/articles/healthand-social-policy/international-city-cooperation-fight-against-covid-19-behind $>$, s. 4-5. 
poziom wielopoziomowego zarządzenia. Jak zauważyła Ileana M. Porras, „[w] przypadku braku silnego przywództwa państw w zakresie zmian klimatycznych, miasta zaproponowały wkroczenie $w$ ten wyłom i zostały przyjęte z otwartymi ramionami przez społeczność międzynarodową" ${ }^{\prime 64}$.

W opinii autorów niniejszego artykułu odpowiedzi na pytania badawcze są pozytywne - miasta mogą pomóc naprawić, a nawet uratować system multilateralny. Współpracują one dwustronnie i wielostronnie, aby rozwiązać takie globalne problemy jak zmiana klimatu czy trwająca pandemia. Doskonale wpisują się też $\mathrm{w}$ wielopoziomowe ramy zarządzania, które zyskują na znaczeniu i uznaniu, zwłaszcza gdy tworzą potężne sieci miast, zwielokrotniając w ten sposób swój potencjał i mocne strony. Wprowadzenie aktów subnarodowych do procesów decyzyjnych oraz wielopoziomowe zarządzanie wzmocniło miasta i zapewniło większy dostęp do wszelkiego rodzaju wiedzy: „nieformalne i nieuporządkowane zarządzanie odnosi się do uporządkowanego i formalnego zarządzania i nakłada się na nie" ${ }^{\prime 65}$. Dziś miasta mogą być doskonale połączone w sieci różnych podmiotów międzynarodowych, w tym sieci miast. I - co ważne - miasta działają „na skalę i poprzez aktywności znajdujące się poza zasięgiem instytucji krajowych" ${ }^{\prime \prime 6}$. Należy również zauważyć, że globalne wysiłki miast mogą przyczynić się do utrzymania międzynarodowego pokoju i porządku opartych na współpracy wielostronnej. W przypadku państw będzie to zależało od ich woli politycznej, gdyż bardzo często takie projekty pozostają w sferze planów, a nie realnych działań. Miasta natomiast są bardzo pragmatyczne i, jak pokazują podane wyżej przykłady, nie tylko debatują i wymieniają się pomysłami, ale także je wdrażają.

Simon Curtis w swojej książce podkreśla, że pomimo rezyǵnacji ze znacznej części ich dawnych praw i obowiązków związanych z suwerennością, państwa nadal są najważniejszym elementem systemu międzynarodowego. Ponieważ jednak środowisko międzynarodowe nie jest systemem

64 I. Porras, The city and international law. In pursuit of sustainable development, „Fordham Urban Law Journal” 2009, t. 36, nr 3, s. 592.

65 P. Stephenson, Twenty years of multi-level governance: 'Where does it come from? What is it? Where is it going?', "Journal of European Public Policy" 2013, t. 20, nr 6, s. 824 .

66 Cities and sovereignty..., s. 1. 
danym raz na zawsze (niezmiennym), ale raczej ewoluującym, a ponadto powstają inne podmioty, które mogą rzucić wyzwanie państwom, wydaje się, że istnieje potencjał dla formy selekcji instytucjonalnej podobnej do procesu, który doprowadził do dominacji państw we wczesnej epoce nowożytnej. Taki wybór zmusi państwa do konkurowania z innymi uprawnionymi aktorami i procesami. Jest to konkurs, w którym państwa kierują się własną logiką terytorialności, a inni aktorzy - w tym globalne miasta - kierują się stojącą wobec niej w sprzeczności zdeterytorializowaną logiką ${ }^{67}$. Wniosek ten z pewnością może odnosić się nie tylko do miast globalnych, ale do miast w ogóle, ponieważ obecnie wszystkie miasta wykazują pewne przejawy globalizacji w swoich działaniach.

\section{Bibliografia}

About America's Pledge, America's Pledge, [dostęp: 8 II 2021], dostępny w internecie: 〈https://www.americaspledgeonclimate.com/about/〉.

Alger Ch. F., The UN system and cities in global governance, Springer, Cham 2014.

Auby J.-B., Mega-cities, 'Glocalisation and the law of the future', [w:] The law of the future and the future of law, red. S. Muler et al., Torkel Opsahl Academic EPublisher, Oslo 2011.

Aust H.-P., Shining cities on the hill? The global city, climate change, and international law, „European Journal of International Law”, 2015, t. 26, nr 1.

Barcelona, global city. International relations master plan 2020-2023, Ajuntament de Barcelona, July 2020, [dostęp: 8 II 2021], dostępny w internecie: <https:// ajuntament.barcelona.cat/relacionsinternacionalsicooperacio/sites/default/ files/bcn_ir_master_plan.pdf $>$.

Betsill M. M., Bulkeley H., Cities and the multilevel governance of global climate change, "Global Governance" 2006, t. 12, nr 2.

Blank Y., The city and the world, "Columbia Journal of Transnational Law” 2006, t. 44 .

Caporaso J. A., International relations theory and multilateralism. The search for foundations, „International Organization” 1992, t. 46, nr 3.

Cities and global governance. New sites for international relations, red. M. Amen et al., Ashgate, Farnham 2011.

Cities and sovereignty. Identity politics in urban spaces, red. D. E. Davis, N. L. de Duren, Indiana University Press, Bloomington, Indianapolis, 2011.

Cities' response to COVID-19, UNESCO, [dostęp: 8 II 2021], dostępny w internecie: $\langle$ https://en.unesco.org/creative-cities/content/cities-response-covid-19〉.

67 S. Curtis, Global cities..., s. 211. 
City diplomacy. Current trends and future prospects, red. A. Sohaela, E. Sevin, Palgrave Macmillan, Cham 2020.

Curtis S., Global cities and the transformation of the international system, ProQuest, Ann Arbor 2014.

Dimitrova A., Mayors of Bratislava, Budapest, Prague and Warsaw sign Free Cities Pact, The Mayor.eu, 17 XII 2019 [dostęp: 24 VII 2021], dostępny w internecie: <https://www.themayor.eu/en/a/view/mayors-of-bratislava-budapest-pragueand-warsaw-sign-free-cities-pact-3945>.

Eslava L., Hill G., Cities, post-coloniality and international law [online], 29 VI 2020 [dostęp: 8 II 2021], dostępne w Internecie: <https://papers.ssrn.com/sol3/papers. cfm?abstract_id $=3617676>$.

EU-China cities discuss the management of COVID-19, European Commission, 14 IV 2020 [dostęp: 8 II 2021], dostępny w internecie: <from https://ec.europa.eu/regional_policy/en/newsroom/news/2020/o4/14-04-2020-eu-china-cities-discussthe-management-of-covid-19>.

Frug G., Barron D., International local government, „The Urban Lawyer” 2006, t. 38, nr 1. Goal 11: Sustainable cities and communities, UN Sustainable Development Goals, [dostęp: 8 II 2021], dostępny w internecie: <https://www.un.org/ sustainabledevelopment/cities/>.

Grandi L. K., City diplomacy, Palgrave Macmillan, Cham 2020.

Grigolo M., Local governments and human rights. Some critical reflections, „Columbia Human Rights Law Review" 2017, t. 49, nr 1.

Hathaway O., Reengaging on treaties and other international agreements (part I): President Donald Trump's rejection of international law, Just Security, 2 X 2020 [dostęp: 8 II 2021], dostępny w internecie: <https://www.justsecurity.org/72656/ reengaging-on-treaties-and-other-international-agreements-part-i-presidentdonald-trumps-rejection-of-international-law/>.

Hooghe L., Marks G., Multi-level governance and European integration, Rowman \& Littlefield Publishers, Oxford 2001.

ICC List of States-parties, International Criminal Court, [dostęp 8 II 2021], dostępny w internecie: <https:/asp.icc-cpi.int/en_menus/asp/states\%2oparties/pages/ the $\% 2$ ostates $\% 20$ parties $\% 20$ to $\% 2$ the $\% 2$ orome $\% 2$ ostatute.aspx $>$.

Inaugural address: Trump's full speech [online], 21 I 2017 [dostęp: 8 II 2021], dostępny w internecie: <http://edition.cnn.com/2017/o1/20/politics/trump-inauguraladdress/ $>$.

International Urban Cooperation, European Union, [dostęp: 8 II 2021], dostępny w internecie: 〈https://iuc.eu/home>.

Joint Political Declaration within the scope of the virtual mayor's summit in Mannheim, 9 IX 2020 [dostęp: 8 II 2021], dostępny w internecie: <https:// www.mannheim.de/sites/default/files/2020-09/EN_Declaration_formated.pdf $>$.

Karwińska A., Brzosko-Sermak A., Dobrze funkcjonujące miasta. Koncepcje, cechy, perspektywy rozwoju, Wydawnictwo Uniwersytetu Ekonomicznego w Krakowie, Kraków 2014. 
Keohane R. O., Multilateralism. An agenda for research, „International Journal” 1990, t. $45, \mathrm{nr} 4$.

Kohler-Koch B., Research on EU governance: insight from a stock-taking exercise, „Connex Newsletter" 2006, nr 3.

Lackowska M., Miejska polityka „zagraniczna” Koncepcja przeskalowania w doświadczeniach polskich miast, Wydawnictwo Uniwersytetu Warszawskiego, Warszawa 2014.

Lin J., Governing climate change. Global cities and transnational lawmaking, Cambridge University Press, Cambridge 2018.

Martin L. M., Interests, power, and multilateralism, „International Organization” 1992, t. $46, \mathrm{nr} 4$.

Moria fire - cities ready to take in refugees, Eurocities, 10 IX 2020 [dostęp: 8 II 2021], dostępny $\mathrm{w}$ internecie: <https://eurocities.eu/latest/moria-fire-cities-ready-totake-in-refugees/>.

Multi-level governance, red. I. Bache, M. Flinders, Oxford University Press, Oxford 2004.

Oomen B., Baumgärtel M., Frontier cities. The rise of local authorities as an opportunity for International Human Rights Law, „European Journal of International Law" 2018, t. 29, nr 2.

Open letter to UN Secretary-General H. E. Mr. António Guterres, Global Parliament of Mayors, 10 IX 2020 [dostęp: 8 II 2021], dostępny w internecie: <https://globalparliamentofmayors.org/gpm-open-letter-to-un-secretary-general/>.

Pierwsze podpisy Bidena. Anulowat część decyzji poprzednika, TVN24 [online], 21 I 2021 [dostęp 8 II 221], dostępny w internecie: <https://tvn24.pl/swiat/usajoe-biden-anulowal-czesc-decyzji-donalda-trumpa-pierwsze-podpisy-nowegoprezydenta-4978295>.

Ponzio R., Laris J., 75 years on: remaking the case for the United Nations, Just Security, 15 September 2020 [dostęp: 8 II 2021], dostępny w internecie: <https://www.justsecurity.org/72435/75-years-on-remaking-the-case-for-the-united-nations/ $>$.

Porras I., The city and international law. In pursuit of sustainable development, „Fordham Urban Law Journal” 2009, t. 36, nr 3.

The power of cities in international relations, red. S. Curtis, Routledge, New York 2014.

Roberts A., Beyond the globalism/nationalism divide. The rise of cities and corporations seeking international obligations, Opinio Juris, 3 VI 2017 [dostęp: 8 II 2021], dostępny w internecie: <http://opiniojuris.org/2017/o6/o3/beyond-globalismnationalism-divide-rise-cities-corporations-seeking-international-obligations/ $>$.

Rudakowska A., Simon C., International city cooperation in the fight against COVID-19: Behind the scenes security providers, "Global Policy" [online], 3 IX 2020 [dostęp: 8 II 2021], dostępne w Internecie: <https://www. globalpolicyjournal.com/articles/health-and-social-policy/international-citycooperation-fight-against-covid-19-behind $>$.

Ruggie J.G., Multilateralism: the anatomy of an institution, „International Organization" 1992, t. 46, nr 3. 
Schmitter P., Kim S., The experience of European integration and the potential for Northeast Asian integration, "East-West Center Working Papers" [online] 2005, nr 10, dostępny w internecie [dostęp: 23 VII 2021]: <http://www.eastwestcenter. org/sites/default/files/private/PSwpo1o.pdf>.

Stephenson P., Twenty years of multi-level governance: 'Where does it come from? What is it? Where is it going?' "Journal of European Public Policy” 2013, t. 20, nr 6.

Swiney Ch., Foster S., Cities are rising in influence and power on the global stage, Bloomberg City Lab, 15 April 2019 [dostęp: 8 II 2021], dostępny w Internecie: <https://www. citylab.com/perspective/2019/o4/city-leadership-international-policy-mayorsu20-uclg-c40/587089/>.

Swiney Ch., The urbanization of international law and international relations. The rising soft power of cities in global governance, „Michigan Journal of International Law" 2020, t. 41, nr 2.

Szymański W., Pakt wolnych stolic przeciwko populistom, Deutsche Welle [online], 9 XI 2019 [dostęp: 24 VII 2021], dostępny w internecie: <https://www.dw.com/ $\mathrm{pl} /$ pakt-wolnych-stolic-przeciwko-populistom/a-51180702 $>$.

Taylor P. J. et al., Cities in globalization. Practices, policies and theories, Routledge, London 2007.

Van der Pluijm R., Melissen J., City diplomacy: The expanding role of cities in international politics, Netherlands Institute of International Relations Clingendael, The Hague 2007, dostępny w internecie [dostęp: 24 VII 2021]: 〈https://www. uclg.org/sites/default/files/20070400_cdsp_paper_pluijm.pdf $\rangle$.

Wierciszewski M., USA wracaja do porozumienia paryskiego. "Rozpoczyna się nowy wyścig technologiczny”, „Business Insider” [online], 21 I 2021 [dostęp: 8 II 2021], dostępny w internecie: <https://businessinsider.com.pl/finanse/decyzja-joego-bidena-powrot-usa-do-porozumienia-paryskiego-konsekwencje-z-punktu/ qmo39wj>. 